\title{
Effect of Substrate Interactions on In Vitro Fatty Acid Synthesis in Adipose Tissue of Normal and Genetically Obese Mice
}

\author{
E. A. Rath, D. A. Hems, and A. Beloff-Chain \\ Department of Biochemistry, Imperial College, London, England
}

Summary. Fatty acid synthesis was measured in vitro in pieces of adipose tissue from lean and obesehyperglycaemic $(o b / o b)$ mice, using ${ }^{14} \mathrm{C}$-glucose or ${ }^{14} \mathrm{C}$-lactate and ${ }^{3} \mathrm{H}_{2} \mathrm{O}$ to obtain absolute rates of total fatty acid synthesis. In the presence of lipoproteintriglyceride $(2.5 \mu \mathrm{mol} / \mathrm{l})$ metabolic interaction occurred which decreased glucose incorporation into fatty acids by $30 \%$ in lean mouse tissue, but not in obese mouse tissue. In the absence of added insulin, the contribution of glucose to total fatty acid synthesis was $69 \%$ in obese mouse tissue, significantly lower than the value of $87 \%$ obtained in lean mouse tissue. Insulin increased the contribution of glucose to total synthesis in both lean and obese mouse tissues, although the value in obese mouse tissue $(83 \%)$ remained lower than the value in lean mouse tissue $(100 \%)$. Lactate was not a major precursor for fatty acid synthesis. When both lactate $(2 \mathrm{mmol} / \mathrm{l})$ and glucose $(15 \mathrm{mmol} / \mathrm{l})$ were present, the contribution of lactate to total fatty acid synthesis was not increased in obese mouse tissue, suggesting that even in the presence of insulin, about $30 \%$ of the carbon was provided by intracellular precursors.

Key words: Obese-hyperglycaemic, obesity, genetic, mice, fatty acid synthesis, ${ }^{3} \mathrm{H}$ discrimination, substrates, lactate, glucose, ob/ob.

Genetically obese (ob/ob) mice exhibit hyperinsulinaemia and hyperglycaemia, providing a model for metabolism in insulin-resistant diabetes. In these mice, increased hepatic lipogenesis has been consistently demonstrated both in vivo $[1,2,3]$ and in vitro $[4,5]$. Measurement of fatty acid synthesis in adipose tissue has produced conflicting results. In vivo studies have indicated enhanced lipogenesis in the adipose organ $[2,3,6]$. However, studies in vitro show increased synthesis in obese mouse tissue measured by acetate incorporation [7], but an impairment in glucose uptake and insulin-dependent conversion of glucose to fatty acids [8].

High levels of unesterified fatty acid decrease glucose incorporation into fatty acids in adipose tissue [9]. In the obese mouse increased hepatic lipogenesis, increased triglyceride turnover [10], and increased lipoprotein lipase activity in adipose tissue [11], suggest an increased uptake of triglyceride-fatty acid by adipose tissue. We have examined the possibility that increased triglyceride-fatty acid uptake by adipose tissue of obese mice may be a mechanism by which glucose incorporation into fatty acids can be modified, by measuring the effect of lipoprotein-triglyceride (substrate for lipoprotein lipase) on glucose incorporation into fatty acids in adipose tissue in vitro.

It is possible that in the insulin-resistant state metabolites other than glucose may become more important substrates for fatty acid synthesis. An alternative substrate is lactate, which is a major precursor for fatty acid synthesis in rat adipose tissue [12]. To examine this possibility, ${ }^{14} \mathrm{C}$-glucose or ${ }^{14} \mathrm{C}$ lactate incorporation into fatty acids was measured in vitro when both substrates were present at concentrations approximating those in vivo. The discrimination against ${ }^{3} \mathrm{H}$ compared to ${ }^{1} \mathrm{H}$ also was measured, in mouse adipose tissue. This allowed calculations of absolute rates of total fatty acid synthesis from ${ }^{3} \mathrm{H}_{2} \mathrm{O}$ incorporation, independent of carbon precursors, in adipose tissue from lean mice and obese mice.

\section{Materials and Methods}

\section{Animals}

Female mice were obtained from a random-bred closed colony maintained at Imperial College into which the $o b$ gene was incorporated. Lean mice were either heterozygous or homozygous. 
Mice were fed ad libitum on a standard breeding diet (Oxoid Ltd., London). Mice were studied at 5-6 weeks of age, when lean mice weighed approximately $22 \mathrm{~g}$ and obese mice $34 \mathrm{~g}$. Female Sprague-Dawley rats were bred and maintained at Imperial College.

\section{Chemicals}

Crystalline ox insulin, glucagon-free, was prepared and supplied by Burroughs Wellcome Laboratories, Dartford, Kent. Intralipid, a $10 \%(w / v)$ emulsion of soybean oil was obtained from Vestric Ltd., Bristol. Bovine serum albumin (fraction V) was supplied by Miles Laboratories, Stoke Poges, Bucks. Radioactive isotopes were obtained from the Radiochemical Centre, Amersham. All solvents were of analytical grade; these and other chemicals were supplied by May and Baker, Dagenham, Essex.

\section{Tissue Incubations}

White parametrial adipose tissue was taken from non-fasting female mice killed by cervical dislocation between $1000 \mathrm{~h}$ and $1400 \mathrm{~h}$. The region of brown-coloured tissue adjacent to the major blood vessels was removed since its rate of lipogenesis differed from the remaining tissue. Pieces of tissue weighing $20-50 \mathrm{mg}$ were placed in gassed Krebs Ringer bicarbonate buffer ( $\mathrm{pH} 7.4$ ) [13] for a maximum of $15 \mathrm{~min}$ before being blotted, weighed and placed in the incubation medium.

Conditions of incubation were used which gave maximum rates of synthesis. This was dependent on the ratio tissue weight/volume of incubation medium, the size of tissue pieces, and the presence of albumin. Tissue weighing $20-50 \mathrm{mg}$ was incubated at $37^{\circ} \mathrm{C}$ for 1 hour in sealed flasks with $2 \mathrm{ml}$ Krebs Ringer bicarbonate buffer containing $2 \mathrm{~g} / 100 \mathrm{ml}$ defatted bovine serum albumin [14], and glucose, lactate, serum and lipoprotein-triglyceride as required. Insulin when present, had a final concentration of $25 \mathrm{mU} / \mathrm{ml}$, which was found by previous experiments to produce maximal stimulation of lipogenesis in obese mouse adipose tissue. Similar values were required to stimulate oxidation maximally in this tissue [15]. ${ }^{3} \mathrm{H}_{2} \mathrm{O}$ was present at a final specific activity of $250-500 \mu \mathrm{Ci} / \mathrm{ml}$, with $\mathrm{U}^{14} \mathrm{C}$-glucose at $0.1-0.25 \mu \mathrm{Ci} / \mathrm{ml}$ or $\mathrm{U}$ ${ }^{14} \mathrm{C}$-lactate at $0.05 \mu \mathrm{Ci} / \mathrm{ml}$. Lipoprotein-triglyceride was prepared by preincubation of dialysed mouse serum and Intralipid emulsion as previously described [16]. The concentration of Intralipid-triglyceride in the incubation medium was $2.5 \mu \mathrm{mol} / \mathrm{ml}$. Serum was present at $10 \%$ of its circulating concentration, and would contribute many other compounds. It was present in the same concentration in control flasks. After incubation of the tissue for $1 \mathrm{~h}$, it was removed from the incubation medium with forceps and rinsed in ice-cold water before extraction of fatty acids.

Fatty acids were isolated by alkaline hydrolysis of the washed lipid extract obtained by the method of Folch et al. [17], or by direct saponification of the tissue in alcoholic $\mathrm{KOH}(40 \mathrm{~g} / 100 \mathrm{ml}$ $40 \%$ ethanol). Direct saponification of adipose tissue was compared with lipid extraction of the same tissue by the method of Folch et al. [17] followed by hydrolysis. 104\% of the radioactivity in fatty acids (either ${ }^{14} \mathrm{C}$ or ${ }^{3} \mathrm{H}$ ) was recovered by direct hydrolysis of the tissue compared to that recovered by lipid extraction followed by hydrolysis. Simultaneous liquid scintillation counting of the ${ }^{3} \mathrm{H}$ and ${ }^{14} \mathrm{C}$ content of lipids was performed using a channels ratio method [18].

The rate of fatty acid synthesis in tissues was calculated from the quotient: $\mathrm{dpm}$ in tissue fatty acid/dpm per $\mu \mathrm{g}$ in precursor. This value for $\mu \mathrm{g}$ atoms incorporated was converted into $\mu \mathrm{mol}$-acetyl units by dividing by 2 for ${ }^{14} \mathrm{C}$. If there were no discrimination against ${ }^{3} \mathrm{H}$, total synthesis in $\mu$ mol-acetyl units would be obtained by dividing by 4 the quotient for ${ }^{3} \mathrm{H}$. However, since the discrimination against ${ }^{3} \mathrm{H}$ (compared to ${ }^{1} \mathrm{H}$ ) has a value of 2.94 (see Results), to obtain total synthesis in $\mu \mathrm{mol}$-acetyl units, the quotient for ${ }^{3} \mathrm{H}$ was divided by $4 / 2.94$ that is by 1.36 .

Values are expressed as mean \pm SEM. The significance of difference was analysed by Student's $t$-test.

Table 1. Fatty acid synthesis in mouse and rat parametrial adipose tissue in vitro. Tissue from mice (aged $5 \mathrm{wk}$ ) and rats (weighing $180 \mathrm{~g}$ ) was incubated in the presence of $15 \mathrm{mmol} / \mathrm{l}$ glucose and insulin $(25 \mathrm{mU} / \mathrm{ml})$. Results are the mean $\pm \mathrm{SEM}$

\begin{tabular}{lrllll}
\hline \multicolumn{5}{c}{$\begin{array}{l}\mu \text { g-atoms incorporated } \\
\text { into fatty acids/h/g fresh tissue }\end{array}$} & \\
\cline { 2 - 5 } Animal & ${ }^{14} \mathrm{C}$ & ${ }^{3} \mathrm{H}$ & ${ }^{3} \mathrm{H} /{ }^{14} \mathrm{C}$ & observations \\
\hline Rat & $43 \pm 4^{*}$ & $35 \pm 3^{*}$ & $0.80 \pm 0.03^{*}$ & 8 \\
Mouse & $117 \pm 21^{*}$ & $78 \pm 13^{*}$ & $0.68 \pm 0.02^{*}$ & 8 \\
\hline
\end{tabular}

* Values significantly different, $\mathrm{P}<0.001$

\section{Results}

\section{Discrimination against ${ }^{3} \mathrm{H}$}

Adipose tissue from mice and rats was incubated in the presence of insulin, with glucose as the only substrate. In mouse adipose tissue the ${ }^{3} \mathrm{H}:{ }^{14} \mathrm{C}$ ratio of $\mu \mathrm{g}$ atoms incorporated into fatty acid was 0.68 (Table 1). Assuming there was no discrimination against ${ }^{14} \mathrm{C}$ compared to ${ }^{12} \mathrm{C}$, this gave a value of 2.94 for the discrimination against ${ }^{3} \mathrm{H}$ compared to ${ }^{1} \mathrm{H}$, since the ratio $\mathrm{H}: \mathrm{C}$ in fatty acids is $2: 1$. This was significantly different $(\mathrm{P}<0.001)$ from the ${ }^{3} \mathrm{H}:{ }^{14} \mathrm{C}$ ratio of 0.80 in rat adipose tissue, which corresponds to a discrimination factor of 2.50 .

\section{Effect of Lipoprotein-Triglyceride}

There was no significant difference in rates of fatty acid synthesis in adipose tissue from obese mice in the presence of lean or obese mouse serum, or in the presence of triglyceride 'activated' by serum (Table 2). However, in lean mouse adipose tissue, triglyceride incubated with serum from obese mice caused a significant decrease $(\mathrm{P}<0.05)$ both in the incorporation of glucose into fatty acid and in the total rate of fatty acid synthesis, compared to the values obtained with serum alone.

\section{Incorporation of Glucose and Lactate}

In the absence of insulin, glucose incorporation into fatty acid when expressed per $\mathrm{g}$ tissue was similar in lean and obese mouse tissue (Table 3). The total rate of synthesis per $\mathrm{g}$ tissue was greater in obese mouse 
Table 2. Effect of serum and triglyceride on fatty acid synthesis from glucose in parametrial adipose tissue from lean and obese mice (aged $5-6 \mathrm{wk})$. Synthesis was measured in the presence of $25 \mathrm{mmol} / \mathrm{l}$ glucose and insulin $(25 \mathrm{mU} / \mathrm{ml})$. Serum was present at $10 \%$ of its circulating concentration. Lipoprotein-triglyceride was prepared by preincubation of serum with Intralipid. The final concentration of Intralipid triglyceride was $2.5 \mu \mathrm{mol} / \mathrm{ml}$. Results are mean $\pm \mathrm{SEM}$. Serum at $10 \%$ of its circulating cóncentration contained: triglyceride $<0.1 \mu \mathrm{mol} /$ $\mathrm{ml}$ (lean and obese; free fatty acid $<0.03 \mu \mathrm{mol} / \mathrm{ml}$ (lean and obese); insulin $<0.004 \mathrm{mU} / \mathrm{ml}$ (lean), $0.10 \mathrm{mU} / \mathrm{ml}$ (obese). These would be present in both control flasks (serum) an experimental flasks (serum + Intralipid). aa, bb, cc $=$ Pairs of values between which there are significant differences, $\mathrm{P}<0.05$

\begin{tabular}{|c|c|c|c|c|c|}
\hline \multirow[t]{2}{*}{ Additions } & \multirow{2}{*}{$\begin{array}{l}\text { Final conc. } \\
\text { triglyceride } \\
\mu \mathrm{mol} / \mathrm{ml}\end{array}$} & \multicolumn{2}{|c|}{$\begin{array}{l}\text { Fatty acid synthesis } \\
\mu \text { mol-acetyl units/h/g tissue }\end{array}$} & \multirow[t]{2}{*}{$\begin{array}{l}\text { Glucose C } \\
\text { contribution (\%) }\end{array}$} & \multirow[t]{2}{*}{$\begin{array}{l}\text { Number of } \\
\text { observations }\end{array}$} \\
\hline & & Total & Glucose C & & \\
\hline \multicolumn{6}{|l|}{ Lean mouse tissue } \\
\hline Lean mouse serum & $<0.1$ & $20.4 \pm 3$ & $18.8 \pm 2$ & $93 \pm 9$ & 3 \\
\hline Obese mouse serum & $<0.1$ & $22.1 \pm 2^{b}$ & $22.3 \pm 2^{\mathrm{a}}$ & $100 \pm 2$ & 3 \\
\hline Lean mouse serum + Intralipid & 2.6 & $21.8 \pm 3^{\mathrm{c}}$ & $20.7 \pm 3$ & $95 \pm 7$ & 3 \\
\hline Obese mouse serum + Intralipid & 2.6 & $14.4 \pm 1^{\mathrm{b}, \mathrm{c}}$ & $15.1 \pm 1^{\mathrm{a}}$ & $105 \pm 2$ & 3 \\
\hline \multicolumn{6}{|l|}{ Obese mouse tissue } \\
\hline Lean mouse serum & $<0.1$ & $24.5 \pm 3$ & $16.5 \pm 2$ & $73 \pm 5$ & 6 \\
\hline Obese mouse serum & $<0.1$ & $26.2 \pm 3$ & $19.3 \pm 2$ & $74 \pm 2$ & 4 \\
\hline Lean mouse serum + Intralipid & 2.6 & $21.6 \pm 2$ & $17.3 \pm 2$ & $80 \pm 2$ & 5 \\
\hline Obese mouse serum + Intralipid & 2.6 & $23.5 \pm 3$ & $20.0 \pm 2$ & $86 \pm 7$ & 6 \\
\hline
\end{tabular}

Table 3. Contribution of lactate and glucose to total fatty acid synthesis in parametrial adipose tissue from lean and obese mice (aged 5-6 wk). Results are the mean \pm SEM. ${ }^{*},{ }^{* *}$, Values significantly different from those in appropriate obese mouse tissue. aa, bb, cc, dd, ee, ff $=$ Pairs of values between which there are significant differences in the same tissue: ${ }^{a, b, c, d} \mathbf{P}<0.05$; ${ }^{\text {e, f }} \mathrm{P}<0.001$

\begin{tabular}{|c|c|c|c|c|c|c|c|}
\hline \multirow[t]{2}{*}{ Substrates } & \multirow[t]{2}{*}{$\mathrm{mmol} / \mathrm{l}$} & \multicolumn{3}{|c|}{$\begin{array}{l}\text { Fatty acid synthesis } \\
\mu \text { mol-acetyl units } / \mathrm{h} / \mathrm{g} \text { tissue }\end{array}$} & \multicolumn{2}{|c|}{$\begin{array}{l}\text { Contribution to total } \\
\text { synthesis }(\%)\end{array}$} & \multirow[t]{2}{*}{$\begin{array}{l}\text { Number of } \\
\text { observations }\end{array}$} \\
\hline & & Total & Glucose C & Lactate C & Glucose C & Lactate C & \\
\hline \multicolumn{8}{|c|}{ Lean mice: no insulin } \\
\hline glucose & 15 & $13 \pm 3^{* * *}$ & $12 \pm 3$ & - & $87 \pm 4^{e}$ & - & 6 \\
\hline lactate & 2 & $3 \pm 1^{* *}$ & - & $2 \pm 1 * * a$ & - & $46 \pm 5^{*}$ & 4 \\
\hline $\begin{array}{l}\text { glucose } \\
+ \\
\text { lactate }\end{array}$ & $\begin{array}{l}15 \\
2\end{array}$ & $22 \pm 4$ & $12 \pm 2$ & $6 \pm 2^{\mathrm{a}}$ & $52 \pm 3^{* e}$ & $26 \pm 4$ & 7 \\
\hline \multicolumn{8}{|c|}{ Obese mice: no insulin } \\
\hline glucose & 15 & $20 \pm 2$ & $14 \pm 2$ & - & $69 \pm 8^{f}$ & - & 6 \\
\hline lactate & 2 & $21 \pm 3$ & - & $6 \pm 1$ & - & $27 \pm 4$ & 4 \\
\hline $\begin{array}{c}\text { glucose } \\
+ \\
\text { lactate }\end{array}$ & $\begin{array}{r}15 \\
2\end{array}$ & $24 \pm 3$ & $9 \pm 0$ & $4 \pm 0$ & $39 \pm 5^{f}$ & $16 \pm 5$ & 7 \\
\hline \multicolumn{8}{|c|}{ Lean mice: insulin $25 \mathrm{mU} / \mathrm{ml}$} \\
\hline glucose & 15 & $38 \pm 10$ & $39 \pm 11$ & - & $102 \pm 5^{* \mathrm{~b}}$ & - & 5 \\
\hline lactate & 2 & $2 \pm 1 * *$ & - & $1 \pm 0 * * d$ & - & $31 \pm 8$ & 4 \\
\hline $\begin{array}{l}\text { glucose } \\
+ \\
\text { lactate }\end{array}$ & 2 & $41 \pm 9$ & $33 \pm 7$ & $7 \pm 3^{d}$ & $80 \pm 8^{* b}$ & $17 \pm 7$ & 7 \\
\hline \multicolumn{8}{|c|}{ Obese mice: insulin $25 \mathrm{mU} / \mathrm{ml}$} \\
\hline $\begin{array}{l}\text { glucose } \\
\text { lactate }\end{array}$ & $\begin{array}{r}15 \\
2\end{array}$ & $\begin{array}{l}27 \pm 2 \\
12+2\end{array}$ & $23 \pm 2$ & $\overline{2}+0$ & $\begin{array}{c}83 \pm 7^{c} \\
-\end{array}$ & $20 \overline{+} 5$ & $\begin{array}{l}6 \\
4\end{array}$ \\
\hline glucose & 15 & & & & & & \\
\hline $\begin{array}{c}+ \\
\text { lactate }\end{array}$ & 2 & $31 \pm 4$ & $18 \pm 4$ & $4 \pm 1$ & $59 \pm 6^{c}$ & $13 \pm 3$ & 7 \\
\hline
\end{tabular}


tissue. Thus the contribution of glucose to total fatty acid synthesis was greater in lean mouse tissue than in obese mouse tissue. In the presence of insulin, glucose incorporation increased $3 \times$ in lean mouse tissue, but by only $50 \%$ in obese mouse tissue. The glucose carbon contribution of $102 \pm 5 \%$ confirmed the discrimination factor obtained from Table 1. However, in obese mouse tissue, there was a significant carbon deficit of about $17 \%$ of the total rate of synthesis.

When lactate was the sole precursor, the incorporation of lactate carbon into fatty acids, expressed per $\mathrm{g}$ tissue, was significantly greater $(\mathrm{P}<0.001)$ in obese mouse tissue. The total rates of synthesis per $\mathrm{g}$ tissue were also significantly greater $(\mathrm{P}<0.001)$, the lactate incorporation being associated with a significant carbon deficit. In obese mouse tissue the deficit was about $70-80 \%$ of the total rate of synthesis. In lean mouse tissue the value was $50-70 \%$. Insulin did not stimulate fatty acid synthesis from lactate.

When both precursors were present, substrate interaction differed in lean and obese mouse tissues. In lean mouse tissue, glucose markedly stimulated lactate incorporation $(\mathrm{P}<0.05)$ especially in the presence of insulin. In obese mouse tissue, there was no significant stimulation of lactate incorporation by glucose. In the presence of insulin, the glucose contribution fell significantly $(P<0.05)$ in the presence of lactate to $80 \%$, and lactate contributed $17 \%$ to total fatty acid synthesis in lean mouse tissues. In obese mouse tissues, the glucose contribution to total synthesis also fell significantly $(\mathrm{P}<0.05)$ in the presence of lactate to $59 \%$, lactate contributed $13 \%$ and endogenous precursors presumably supported about $30 \%$ of total synthesis.

\section{Discussion}

Earlier measurements of fatty acid synthesis in mice using ${ }^{3} \mathrm{H}$ incorporation from ${ }^{3} \mathrm{H}_{2} \mathrm{O}[3,5]$ calculated absolute rates of fatty acid synthesis using a factor of 2.4 to correct for the discrimination against ${ }^{3} \mathrm{H}$ compared to ${ }^{1} \mathrm{H}$. This factor was derived for rat liver [19]. Jungas [20] obtained a value of 2.29 for rat adipose tissue. Using Jungas' method (Table 1) we obtained a value of 2.50 for rat adipose tissue, and 2.94 for mouse adipose tissue. The discrimination factor of 2.94 was used to derive rates of total fatty acid synthesis (in $\mu$ mols acetyl units) by dividing the apparent $\mu \mathrm{g}$ atoms ${ }^{3} \mathrm{H}$ incorporated by $4 / 2.94=1.36$.

The greater discrimination against ${ }^{3} \mathrm{H}$ in mouse tissue compared to rat tissue may be due to increased contribution of the pentose phosphate pathway (PPP) to the supply of reducing equivalents for fatty acid synthesis. NADPH generated by the PPP is quantitatively recovered in fatty acids and no exchange occurs between water and hydrogen of NADPH [21]. The greater discrimination against ${ }^{3} \mathrm{H}$ (and thus tritium) and mouse tissue suggests the PPP provided $70-80 \%$ of the reducing equivalents for synthesis, compared with $60 \%$ in rat tissue [20]. Confirmation of this would require an analysis of the ${ }^{3} \mathrm{H}$ distribution on odd- and even-numbered carbon atoms of the fatty acid chain [20].

The hypothesis that increased triglyceride-fatty acid uptake by obese mouse adipose tissue may inhibit glucose incorporation into fatty acids, resulting in decreased glucose utilization was not supported. The data suggested that such inhibition may operate in normal mice, since triglyceride at a concentration approximately 3 times that in vivo [10], prepared as a substrate for lipoprotein lipase, did decrease fatty acid synthesis in the presence of serum. In rat adipose tissue, a concentration of $2.0 \mathrm{mmol} / \mathrm{l}$ free fatty acid was required to inhibit fatty acid synthesis [9]. It is unlikely that the lack of inhibition by triglyceride in obese mice was due to a functional decrease in lipoprotein lipase; it is more likely that it reflected a lower intracellular concentration of fatty acid in obese mouse tissue, which has an enhanced capacity for esterification [22].

Lactate was examined as an alternative substrate for fatty acid synthesis in adipose tissue. Lactate is present in the circulation in significant concentrations [23], and it is a major precursor of fatty acids both in the mouse liver [5] and rat adipose tissue [12]. In addition, in vitro data suggested that obese mouse tissue utilizes lactate faster than lean mouse tissue [24]. Comparison of rates of fatty acid synthesis per g tissue does not compare the activity in adipocytes of lean and obese mice, since obese mouse adipose tissue contains fewer adipocytes of increased size. Thus rates per $\mathrm{g}$ tissue tend to underestimate rates of fatty acid synthesis in obese mouse tissue. However, comparison of the relative importance of the two substrates is valid. When both glucose and lactate were present at concentrations approximating those in vivo, it was found that unlike the liver, lactate was not a major precursor for fatty acid synthesis (supporting about $17 \%$ of the total). Moreover, lactate did not become a more important precursor in the insulin-resistant adipose tissue of the obese mouse.

Lactate utilization appeared to be associated with a large contribution $(50-80 \%)$ by intracellular precursors to total fatty acid synthesis. It is possible that this is an overestimate. When no glucose is present, the activity of the PPP would be minimal and the discrimination factor of 2.94 would be too high. Total synthesis may be overestimated by up to $75 \%$. However, lactate carbon incorporation would still be insufficient to account for total synthesis. In the 
presence of lactate, intracellular precursors would support a minimum of $25-65 \%$ of total fatty acid synthesis.

A greater proportion of fatty acid synthesis also appeared to be maintained by intracellular precursors in obese mouse adipose tissue compared to lean mouse tissue, as suggested by Christophe et al. [25]. It is unlikely that this is an artefact caused by the discrimination factor being too high, due to a decreased role of the PPP in obese mouse adipose tissue [26]. Enzyme activity measurements indicated an elevated role for the PPP, since the activity of 6-Pgluconate dehydrogenase was increased, whereas the activity of malic enzyme was not [27].

It is possible that a major intracellular precursor of fatty acids was glycogen. Glycogen facilitates lactate utilization [21], and the increased utilization of lactate (in the absence of glucose) and the greater carbon deficit in obese tissue may reflect the higher concentration of glycogen [28]. The glycogen concentration of about $1 \mu \mathrm{mol}$ glycogen-glucose $/ \mathrm{g}$ reported by these authors would be insufficient to support the rates of synthesis observed in obese mice, suggesting other metabolites such as amino-acids may play a significant role as fatty precursors in obese mouse adipose tissue.

Acknowledgements. We thank the British Diabetic Association and the Wellcome Trust for their support.

\section{References}

1. Bates MW, Zomzely C, Mayer J (1955) Fat metabolism in three forms of experimental obesity. IV. Instantaneous rates of lipogenesis in vivo. Am J Physiol 181: 187-190

2. Loten EG, Rabinovitch A, Jeanrenaud B (1974) In vivo studies on lipogenesis in obese hyperglycaemic (ob/ob) mice: possible role of hyperinsulinaemia. Diabetologia 10: 45-52

3. Hems DA, Rath EA, Verrinder TR (1975) Fatty acid synthesis in liver and adipose tissue of normal and genetically obese (ob/ob) mice during the 24-hour cycle. Biochem J 150 : $167-173$

4. Assimacopoulos-Jeannet F, Singh A, Le Marchand Y, Loten EG, Jeanrenaud B (1974) Abnormalities in lipogenesis and triglyceride secretion by perfused livers of obese-hyperglycaemic (ob/ob) mice: relationship with hyperinsulinaemia. Diabetologia 10: 155-162

5. Salmon DMW, Bowen NL, Hems DA (1974) Synthesis of fatty acids in the perfused mouse liver. Biochem $\mathbf{J} 142$ : 611-618

6. Jansen GR, Zanetti MW, Hutchinson CF (1967) Studies of lipogenesis in vivo. Fatty acid and cholesterol synthesis in hyperglycaemic-obese mice. Biochem J 102: 870-877

7. Christophe J, Jeanrenaud B, Mayer J, Renold AE (1961) Metabolism in vitro of adipose tissue in obese-hyperglycaemic and goldthioglucose-treated mice. II. Metabolism of pyruvate and acetate. J Biol Chem 236: 648-652

8. Christophe J, Jeanrenaud B, Mayer J, Renold AE (1961) Metabolism in vitro of adipose tissue in obese-hyperglycemic and goldthioglucose-treated mice. I. Metabolism of glucose. J Biol Chem 236: 642-647
9. Saggerson ED (1972) The regulation of glyceride synthesis in isolated white fat cells. The effect of palmitate and lipolytic agents. Biochem J 128: 1057-1067

10. Salmon DMW, Hems DA (1973) Plasma lipoproteins and the synthesis and turnover of plasma triglyceride in normal and genetically obese mice. Biochem J 136: 551-563

11. Enser M (1972) Clearing-factor lipase in obese-hyperglycaemic mice (ob/ob). Biochem J 129: 447-453

12. Katz J, Wals PA (1974) Lipogenesis from lactate in rat adipose tissue. Biochim Biophys Acta 348: 344-356

13. Krebs HA, Henseleit K (1932) Untersuchungen über die Harnstoffbildung im Tierkörper. Hoppe Seylers Z Physiol Chem 210: 33-66

14. Chen $R$ (1967) Removal of fatty acids from serum albumin by charcoal treatment. J Biol Chem 242: 173-181

15. Abraham RR, Beloff-Chain A (1971) Hormonal control of intermediary metabolism in obese hyperglycemic mice. I. The sensitivity and response to insulin in adipose tissue and muscle in vitro. Diabetes 20: $522-534$

16. Rath EA, Hems DA, Beloff-Chain A (1974) Lipoprotein lipase activities in tissues of normal and genetically obese (ob/ ob) mice. Diabetologia 10:261-265

17. Folch J, Lees M, Sloane-Stanley GH (1957) A simple method for the isolation and purification of total lipides from animal tissue. J Biol Chem 226: 497-509

18. Hendler RW (1964) Procedure for simultaneous assay of two B-emitting isotopes with the liquid scintillation counting technique. Anal Biochem 7: 110-120

19. Eidinoff ML, Perri GC, Knoll JE, Marano BJ, Arnheim J (1953) The fractionation of hydrogen isotopes in biological systems. J Am Chem Soc 75: 248-249

20. Jungas RL (1968) Fatty acid synthesis in adipose tissue incubated in tritiated water. Biochemistry 7: 3708-3717

21. Schmidt K, Katz J (1969) Metabolism of pyruvate and L-lactate by rat adipose tissue. J Biol Chem 244: 2125-2131

22. Jamdar S, Shapiro D, Fallon H (1976) Triacylglycerol biosynthesis in the adipose tissue of the obese-hyperglycaemic mouse. Biochem J 158: 327-334

23. Elliott J, Dade E, Salmon DMW, Hems DA (1974) Hepatic metabolism in normal and genetically obese mice. Biochim Biophys Acta 343: 307-323

24. Rath EA, Beloff-Chain A, Hems DA (1975) Contribution of lactate carbon to fatty acid synthesis in adipose tissue of normal and genetically obese (ob/ob) mice. Biochem Soc Trans 3: 513-515

25. Christophe J, Dehaye J, Winand J (1974) Utilization in vitro of $\mathrm{U}^{14} \mathrm{C}$ glucose, $\mathrm{U}^{14} \mathrm{C}$ fructose, $\mathrm{L} \mathrm{U}^{14}{ }^{14} \mathrm{C}$ alanine and ${ }^{3} \mathrm{H}$ water in adipose-tissue fragments from Bar Harbor obesehyperglycaemic mice. Biochem Soc Trans 2: 1214-1215

26. Flatt JP (1970) Conversion of carbohydrate to fat in adipose tissue: an energy-yielding and, therefore, self-limiting process. J Lipid Res 11: 131-143

27. Martin RJ, Welton RF, Baumgardt BR (1973) Adipose and liver tissue enzyme profiles in obese hyperglycemic mice. Proc Soc Exp Biol Med 142: 241-245

28. Kaplan ML, Fried GH (1973) Adaptive enzyme responses in adipose tissue of obese hyperglycaemic mice. Arch Biochem Biophys 158: 711-719

Received: May 22, 1979, and in revised form: January 21, 1980

Dr. E. A. Rath

School of Biological Sciences

Queen Mary College

Mile End Road

London E1 4NS

England 